\title{
$\beta$-conglycinin combined with fenofibrate or rosuvastatin have exerted distinct hypocholesterolemic effects in rats
}

\author{
Ederlan S Ferreira, Maraiza A Silva, Aureluce Demonte and Valdir A Neves
}

\begin{abstract}
Background: There is increasing interest in non-pharmacological control of cholesterol and triglyceride levels in the plasma and diet-drug association represent an important area of studies. The objective of this study was to observe the hypocholesterolemic effect of soybean $\beta$-conglycinin (7S protein) alone and combined with fenofibrate and rosuvastatin, two hypolipidemic drugs.

Methods: The protein and drugs were administered orally once a day to rats and the effects were evaluated after 28 days. Wistar rats were divided into six groups $(n=9)$ : hypercholesterolemic diet $(\mathrm{HC}), \mathrm{HC}+7 \mathrm{~S}$ protein $(300 \mathrm{mg} . \mathrm{kg}-1$ day-1) (HC-7S), HC+fenofibrate (30 mg.kg-1 day-1)(HC-FF), HC+rosuvastatin (10 mg.kg-1 day-1)(HC-RO), $\mathrm{HC}+7 \mathrm{~S}+$ fenofibrate (HC-7S-FF) and HC+7S+rosuvastatin (HC-7S-RO).

Results: Animals in HC-7S, HC-FF and HC-RO exhibited reductions of 22.9, 35.8 and $18.8 \%$ in total plasma cholesterol, respectively. In HC-7S-FF, animals did not show significant alteration of the level in HC+FF while the group HC-7S-RO showed a negative effect in comparison with groups taking only protein (HC-7S) or drug (HC-RO). The administration of the protein, fenofibrate and rosuvastatin alone caused increases in the plasma HDL-C of the animals, while the protein-drug combinations led to an increase compared to HC-FF and HC-RO. The plasma concentration of triacylgycerides was significantly reduced in the groups without association, while HC-7S-FF showed no alteration and HC-7S-RO a little reduction.
\end{abstract}

Conclusion: The results of our study indicate that conglycinin has effects comparable to fenofibrate and rosuvastatin on the control of plasma cholesterol, HDL-C and triacylglycerides, when given to hypercholesterolemic rats, and suggests that the association of this protein with rosuvastatin alters the action of drug in the homeostasis of cholesterol.

Keywords: $\beta$-conglycinin, cholesterol-lowering drugs, hypercholesterolemic diet, rats.

\section{Background}

Some proteins and peptides have been under study on account of their important biological function in relation to lipid metabolism [1-3]. Research has demonstrated the importance of leguminous seeds, as a component of the diet including their beneficial effect on the control of cholesterol and triacylglycerols in the blood, with an emphasis on their proteins and in particular soybean proteins $[4,5]$. In vitro and in vivo studies have shown that ingestion of protein isolate and/or protein fractions of soybean, as the sole source of protein or even a daily

\footnotetext{
* Correspondence: nevesva@fcfar.unesp.br

Department of Food and Nutrition, School of Pharmaceutical Sciences, São Paulo State University -UNESP, Araraquara, SP, Brazil
}

dose, improves the control of plasma cholesterol and triglycerides [6-15]. A recent analysis of various studies about the effects of soybean in the diet on the circulation levels of cholesterol indicates a variable reduction in LDL-C (from 7.9 to $10.3 \%$ ) attributed to intrinsic and extrinsic effects of the soy protein foods [16]. Although these studies in various models have achieved progress in this area, the mechanism of the reduction of cholesterol and triacylglycerides in the serum by soybean proteins are still not clear. Nevertheless, the observed effects of soybean proteins was the basis on which the US Food and Drug Administration (FDA) made a recommendation that $25 \mathrm{~g}$ of soybean protein be ingested to decrease total cholesterol and the LDL-cholesterol fraction [17].
C Biomed Central

(C) 2012 Ferreira et al; licensee BioMed Central Ltd. This is an Open Access article distributed under the terms of the Creative Commons Attribution License (http://creativecommons.org/licenses/by/2.0), which permits unrestricted use, distribution, and reproduction in any medium, provided the original work is properly cited. 
A lot of studies have stressed the diet as an important form of intervention, alone or together with drugs, in the context of hyperlipidemia or hypercholesterolemia in their various forms $[4,18]$. The treatment of hyperlipidemia and hypercholesterolemia with a diet-drug combination is well recognized and has been growing in importance in recent times [19]; nevertheless, these combination therapies have received less attention than multi-drug therapy $[18,20]$. Fibrates and their derivatives are hypolipidemic agents widely used in the treatment of combined hyperlipidemias, however they are particularly effective at reducing serum triacylglycerols and improving serum high-density lipoprotein (HDL) [21,22].

Statins are used in the treatment of hypercholesterolemia, and the action of this class of drugs depends on their generation and dose. These drugs have an inhibitory action on cholesterol synthesis via the mevalonate pathway $[18,23]$. The positive effects of $\beta$-conglycinin soybean protein, taken as a daily dose or a sole protein source by rats fed a hypercholesterolemic diet, on TC and TG levels have been described in previous studies [13-15]. However, the combination of this protein with other antihyperlipidemic drugs has not been much reported. Drug-diet approaches may help in controlling the prescription of drugs, but studies are needed to be performed to explore novel combinations and assess the potential safety and effectiveness of the association, comparing its efficacy with treatment by each component alone. To observe of the effect of soybean $\beta$-conglycinin alone and in combination with two drugs effective in the treatment of dyslipidemia, fenofibrate and rosuvastatin, the present study was conducted to determine whether the association of $\beta$-conglycinin soy protein and either drug could result in an alteration of the action of the protein or the drug alone.

\section{Methods}

\section{Isolation and characterization of $\beta$-conglycinin (7S)}

Soybean flour from the local market (60 mesh) was defatted with hexane (1:8 w/v flour to solvent ratio) by rocking at room temperature for $12 \mathrm{~h}$, followed by reextraction in the same solvent $(1: 6 \mathrm{w} / \mathrm{v})$, dried in air at room temperature and used for protein extraction. Soybean $\beta$ conglycinin was isolated by the method of Nagano et al. [24] with some modifications. Defatted soybean flour was extracted by shaking with water $(1: 15 \mathrm{w} / \mathrm{v}$ flour to water ratio) adjusted to $\mathrm{pH} 7.5$. The soluble extract was centrifuged at $2000 \times g$ for $30 \mathrm{~min}$. The supernatant was treated with anhydrous sodium bisulphite $(0.98 \mathrm{~g} / \mathrm{L})$ and the $\mathrm{pH}$ adjusted to 6.4. The solution was stirred and stored on ice overnight, followed by centrifugation at $6500 \times g$ for $20 \mathrm{~min}$. The insoluble fraction, containing $11 \mathrm{~S}$ globulin, was washed, centrifuged again under the same conditions, suspended in distilled water, dialyzed overnight against distilled water in appropriate dialysis sacs (pore size of about $10 \mathrm{kDa}$ ) and lyophilized. The soluble fraction was treated with $0.25 \mathrm{~mol} / \mathrm{L} \mathrm{NaCl}$ and adjusted to $\mathrm{pH} 5.0$ and, after $1 \mathrm{~h}$, centrifuged at $9000 \times g$ for $30 \mathrm{~min}$. The precipitate (7S or $\beta$-conglycinin) was solubilized in $0.25 \mathrm{~mol} / \mathrm{L}$ sodium phosphate buffer $(\mathrm{pH} 7.0)$ and stored at $-14^{\circ} \mathrm{C}$. All steps were realized at $4^{\circ} \mathrm{C}$. All chemicals were of analytical purity. Protein was determined by the method of Lowry et al. [25], using bovine serum albumin (BSA) as a standard. Electrophoresis of 7S-globulin was performed on $10 \mathrm{~g} / 100 \mathrm{~g}$ polyacrylamide gels containing $0.1 \%$ sodium dodecyl sulfate (SDS), as described by Laemmli [26], in a Mini Protean II cell (Bio-Rad, Hercules, CA, USA)(SDSPAGE). The gels were stained in Coomassie Brilliant Blue (R-250) and destained by diffusion in methanol-acetic acid-water (1:1:8, v/v/v). Marker proteins of known molecular weight $(\mathrm{MW})$ were rabbit muscle phosphorylase $b$, bovine serum albumin, hen egg white albumin, bovine carbonic anhydrase, soybean trypsin inhibitor and hen egg white lysozyme. Gel images were digitalized and analyzed by densitometry with an alpha Imager 6.0 scanner (Alpha Innotech $^{\circledR}$, San Leandro, CA, USA), to quantify the bands and level of purity (data not shown). The content and homogeneity of the isolated $\beta$-conglycinin and glycinin, determined by SDS-PAGE and densitometric gel analysis, showed that these were the main fractions. The gels showed the characteristic bands for subunits $\alpha, \alpha$ and $\beta$ of conglycinin (7S). The procedure used to isolate $7 \mathrm{~S}$ did not cause changes in the subunits; this step was essential to ensure a pure protein, suitable for the in vivo studies [15].

\section{Animals, diets and experimental design}

This study was performed with the approval of the Committee on Animal Research of the University (UNESP) and these experiments were approved by the Research Ethics Committee of the School of Pharmaceutical Sciences, São Paulo State University (UNESP) at Araraquara (res. 19/2007). All procedures were performed in accordance with the principles in the Guide for the Care and Use of Laboratory Animals (National Research Council, 1985). Fifty-four male weanling Wistar rats, weighing $148 \pm 12.3 \mathrm{~g}$ were obtained from the Central Laboratory for animals of UNESP at Botucatu. The animals were acclimatized for a week and fed standard laboratory rat chow (Purina ${ }^{\circledR}$ ). After this period, they were randomly divided into 6 hypercholesterolemic groups (HC) $(n=9)$ : (1) control HC; (2) 7S globulin, $300 \mathrm{mg} \cdot \mathrm{kg}^{-1} \mathrm{day}^{-1}(\mathrm{HC}+7 \mathrm{~S})$; (3) fenofibrate group $\left(\mathrm{HC}+\mathrm{FF}, 30 \mathrm{mg} \cdot \mathrm{kg}^{-1} \mathrm{day}^{-1}\right) ;(4)$ rosusvatatin group (HC +RO $10 \mathrm{mg} \cdot \mathrm{kg}^{-1} \mathrm{day}^{-1}$ ); (5) $\beta$-conglycinin/fenofibrate group $\left(\mathrm{HC}+7 \mathrm{~S}+\mathrm{FF}, 300\right.$ and $\left.30 \mathrm{mg} \cdot \mathrm{kg}^{-1} \mathrm{day}^{-1}\right)$ and (6) $\beta$ conglycinin/rosuvastatin group $(\mathrm{HC}+7 \mathrm{~S}+\mathrm{RO}, 300$ and $10 \mathrm{mg} \cdot \mathrm{kg}^{-1} \mathrm{day}^{-1}$ ). All HC groups were fed an AIN-93 diet, following the recommendation of American 
Institute Nutrition 93-Maintenance [27], modified by adding $10 \mathrm{~g} \cdot \mathrm{kg}^{-1}$ cholesterol and $5 \mathrm{~g} . \mathrm{kg}^{-1} \mathrm{~g}$ cholic acid $[13,28]$, as described in Table 1 . Animals were individually housed in stainless steel cages, with free access to food and water. The room temperature was maintained at a constant $23 \pm 2^{\circ} \mathrm{C}$ and relative humidity at $60 \pm 5 \%$, with a 12-12 h light:dark cycle, lights on at 6:00 a.m. The proteins ( $7 \mathrm{~S}$ globulins) and drugs were administered daily by gavage at 9:00 and 14:00 hours, in proportion to the body weight of each animal, while vehicle alone was administered to HC groups. Body weight, food intake, fecal excretion and feeding efficiency were measured every other day for comparative analysis between groups during the 28 days of the experiment. The feeding efficiency coefficient was calculated as the ratio of weight gain/daily intake $\times 100$.

\section{Blood collection, organ weight and tissue collection}

On the last day, the animals were deprived of food for $12 \mathrm{~h}$ and euthanized by guillotine. Blood was then collected in tubes containing gel separator SST II (Vacutainer BD D ${ }^{\circledR}$, Franklin Lakes, NJ, USA) and centrifuged at $1900 \times g$ for $15 \mathrm{~min}$. The serum was separated, stored at $-24^{\circ} \mathrm{C}$ and used for biochemical analysis. Retroperitoneal fat, liver and heart were removed, washed immediately in cold saline, dried and weighed, frozen and stored at $-40^{\circ} \mathrm{C}$ for a period of less than a month for subsequent comparative analysis.

\section{Biochemical analysis in plasma and liver}

Plasma total cholesterol (TC) of all groups was measured by the liquid cholesterol CHOD-PAP method described by Stockbridge et al. [29]. Serum high density lipoprotein (HDL-C) was measured by the HDL cholesterol precipitant method, as described by Assmann [30]. Triglycerides (TG) were measured by the liquid triglyceride GPO-PAP method, as described by Annoni et al. [31]. All analyses were carried out by enzymatic colorimetric methods, using commercially available reagent kits (Laborlab ${ }^{\circledR}$ Co., Ribeirão Preto, Brazil). The nonHDL-cholesterol fraction (non-HDL-C or LDL-C + VLDL-C) was calculated as the difference between the $\mathrm{TC}$ and HDL-C. The atherogenic index (AI) (TC-HDLC/HDL-C) was calculated, as proposed by Liu et al. [32], and compared among groups. Hepatosomatic index (HIS) was calculated as follows: liver weight/body weight $\times 100$. Liver lipids were extracted by the method of Haug et al. [33]. The liver TC and TG concentrations were measured as described earlier for plasma analysis.

\section{Statistical Analysis}

Data were analyzed by one-way analysis of variance (ANOVA) and Bonferroni t-test multiple comparisons versus the control group and multiple range tests, employing SigmaStat ${ }^{\circledR} 3.5$ software (Dundas software, Germany, 1999). All values are presented as mean \pm standard error for nine values per group. A difference was considered statistically significant when $P<0.05$.

\section{Results}

Isolation of the soybean $\beta$-conglycinin

SDS-PAGE electrophoresis, conducted on the 7S globulin after separation from other protein components in soybean flour, showed the characteristic bands of

Table 1 Composition ( $\mathrm{g} / \mathrm{kg}$ diet) of the hypercholesterolemic diet and treatments by gavage*

\begin{tabular}{|c|c|c|c|c|c|c|}
\hline \multirow[t]{2}{*}{ Ingredient } & \multicolumn{6}{|c|}{ Diets } \\
\hline & $\mathrm{HC}$ & $\mathrm{HC}+7 \mathrm{~S}$ & $\mathrm{HC}+\mathrm{FF}$ & $\mathrm{HC}+\mathrm{RO}$ & $\mathrm{HC}+7 \mathrm{~S}+\mathrm{FF}$ & $\mathrm{HC}+7 \mathrm{~S}+\mathrm{RO}$ \\
\hline Casein $^{1}$ & 150 & 150 & 150 & 150 & 150 & 150 \\
\hline Starch & 590.57 & 590.87 & 590.87 & 590.87 & 590.87 & 590.87 \\
\hline Sucrose & 100 & 100 & 100 & 100 & 100 & 100 \\
\hline Soybean oil & 40 & 40 & 40 & 40 & 40 & 40 \\
\hline Cellulose powder & 50 & 50 & 50 & 50 & 50 & 50 \\
\hline Mineral mixture ${ }^{2}$ & 35 & 35 & 35 & 35 & 35 & 35 \\
\hline Vitamin mixture ${ }^{2}$ & 10 & 10 & 10 & 10 & 10 & 10 \\
\hline L-Cystine & 1.8 & 1.8 & 1.8 & 1.8 & 1.8 & 1.8 \\
\hline Choline birtatrate & 2.5 & 2.5 & 2.5 & 2.5 & 2.5 & 2.5 \\
\hline Cholesterol $^{3}$ & 1 & 1 & 1 & 1 & 1 & 1 \\
\hline Cholic acid $^{1}$ & 5 & 5 & 5 & 5 & 5 & 5 \\
\hline \multicolumn{7}{|c|}{ Treatment (mg/kg/day) } \\
\hline$\beta$-conglycinin & - & 300.0 & - & - & 300 & 300 \\
\hline Fenofibrate & - & - & 30 & - & 30 & - \\
\hline Rosuvastatin & - & - & - & 10 & - & 10 \\
\hline
\end{tabular}

${ }^{*} \mathrm{HC}=$ hypercholesterolemic diet (AIN-93 composition $+1 \%$ cholesterol and $0.5 \%$ cholic acid); $\mathrm{HC}+7 \mathrm{~S}=\mathrm{HC}$ diet $+\beta$-conglycinin $300 \mathrm{mg} / \mathrm{Kg} / \mathrm{day} ; \mathrm{HC}+\mathrm{FF}=\mathrm{HC}$ diet + fenofibrate $30 \mathrm{mg} / \mathrm{kg} /$ day; $\mathrm{HC}+\mathrm{RO}=\mathrm{HC}$ diet + rosuvastatin $10 \mathrm{mg} / \mathrm{kg} /$ day; $\mathrm{HC}+7 \mathrm{~S}+\mathrm{FF}=\mathrm{HC}$ diet $+\beta$-conglycinin + fenofibrate 300 and $30 \mathrm{mg} / \mathrm{kg} / \mathrm{day}$ and $\mathrm{HC}$ $+7 \mathrm{~S}+\mathrm{RO}=\mathrm{HC}$ diet $+\beta$-conglycinin + rosuvastatin 300 and $10 \mathrm{mg} / \mathrm{kg} /$ day. ${ }^{1}$ Sigma-Aldrich, Co., USA, ${ }^{2}$ PragSoluções ${ }^{\circledR}, C$, Co., Brazil. ${ }^{3}$ Reagen, Co., USA. 
conglycinin (7S), arising from $\alpha, \alpha^{\prime}, \beta$ polypeptide subunits, and densitometric gel analysis showed that this was the main fraction, containing $92.2 \%$ of the protein. The isolation procedure did not cause any change in the subunits and was important to obtain purified protein suitable for the in vivo studies $[14,15]$. Our previous results and those decribed by Duranti et al. [13] have shown that the addition of $1 \%$ cholesterol and $0.5 \%$ cholic acid to the AIN-diet is sufficient to induce hypercholesterolemia and hypertriglyceridemia in rats. The mechanism of these effects on the lipid metabolism of rats was reported by Wang et al. [34], recently.

$\beta$-conglycinin protein and drugs were given by gavage in single daily doses in the experimental design as described in methods. Table 2 shows the effects of daily administration of $\beta$-conglycinin, fenofibrate and rosuvastatin alone and in drug-protein combinations, on the food consumption, weight gain, feeding efficiency ratio and fecal excretion of rats fed the cholesterol-enriched diets. After 28 days, no statistical differences $(p>0.05)$ were found in body weight gain between groups during the experimental period, nor any significant $(p>0.05)$ alterations in the feeding efficiency ratio or food intake between groups (Table 2). However, the animal fecal excretion of the HC group was higher by 18.1, 18.1, 42.9, 21.7 and $50.7 \%$ than groups $\mathrm{HC}+7 \mathrm{~S}, \mathrm{HC}+\mathrm{FF}, \mathrm{HC}+\mathrm{RO}, \mathrm{HC}+7 \mathrm{~S}+\mathrm{FF}$ and $\mathrm{HC}+7 \mathrm{~S}$ $+\mathrm{RO}$, respectively $(p<0.001)$, despite the lack of differences in food intake or feeding efficiency ratio between groups. However, the rosuvastatin-treated animals did show an intake $8.72 \%$ higher than $\mathrm{HC}$ animals $(p<0.001)$. The fenofibrate and rosuvastatin groups showed increases of 55.8 and $63.2 \%(p<0.001)$, and 26.1 and $21.1 \%(p<$ $0.05)$, in the relative liver weight and in the hepatosomatic index (HIS), respectively (Table 3). The simultaneously administration of protein and drugs reduced these effects by 8.4 and $16.1 \%$ for fenofibrate $(\mathrm{HC}+7 \mathrm{~S}+\mathrm{FF})$ and 24.8 and $16.7 \%$ for rosuvastatin $(\mathrm{HC}+7 \mathrm{~S}+\mathrm{RO})$, relative to groups $\mathrm{HC}+\mathrm{FF}$ and $\mathrm{HC}+\mathrm{RO}$, respectively. Alterations in heart weight and the ratio heart weight/body weight were not observed.

\section{Effects on plasma lipids}

The levels of plasma lipids in group $\mathrm{HC}$ were significantly different $(p<0.001)$ from those fed a standard diet [14]; these animals showed a $43.6 \%$ reduction in HDL-C levels and an increase in non-HDL-C and in the atherogenic index of 4 and 7 times, relative to a group on the standard diet in the first part of this study [15]. Relative to $\mathrm{HC}$ groups $\mathrm{HC}+7 \mathrm{~S}, \mathrm{HC}+\mathrm{FF}$ and $\mathrm{HC}+\mathrm{RO}$ had their total plasma cholesterol (TC) reduced by $22.9(p<0.01), 35.8$ $(p<0.001)$ and $18.8 \%(p<0.05)$, respectively (Table 4$)$. There was no significant alteration in the animals that received the $7 \mathrm{~S}$ protein plus fenofibrate $(\mathrm{HC}+7 \mathrm{~S}+\mathrm{FF})$, whereas the association of protein plus rosuvastatin ( $\mathrm{HC}$ $+7 \mathrm{~S}+\mathrm{RO}$ ) caused a negative effect, when the TC levels of these groups were compared with those administered only protein $(\mathrm{HC}+7 \mathrm{~S})$ or drug $(\mathrm{HC}+\mathrm{FF}$ and $\mathrm{HC}+\mathrm{RO})$. For the fraction non-HDL-C, a similar effect was observed with reductions of 33.2, 53.1 and $28 \%(p<0.001)$ for groups $\mathrm{HC}+7 \mathrm{~S}, \mathrm{HC}+\mathrm{FF}$ and $\mathrm{HC}+\mathrm{RO}$, respectively, while decreases of $59.5(p<0.001)$ and $15.2 \%(p<0.05)$ were registered for groups $\mathrm{HC}+7 \mathrm{~S}+\mathrm{FF}$ and $\mathrm{HC}+7 \mathrm{~S}+\mathrm{RO}$. In contrast to rosuvastatin, the protein-fenofibrate association led to an increase of $11.2 \%(\mathrm{p}<0.05)$ (Table 4$)$. The administration of the protein, fenofibrate and rosuvastatin alone caused increases in the plasma HDL-C of the animals by 55.6, 95.6 e $51.1 \%$ in relation to $\mathrm{HC}$, respectively, $(p<0.001)$, while the protein-drug associations led to increases of 6 and $37 \%$, compared to $\mathrm{HC}+\mathrm{FF}$ and $\mathrm{HC}+\mathrm{RO}$ groups, respectively $(p>0.05)$ (Table 4$)$. The atherogenic index (AI) showed decreases of $56.5,75.8$ and $49.4 \%$ in $\mathrm{HC}+7 \mathrm{~S}$, $\mathrm{HC}+\mathrm{FF}$ and $\mathrm{HC}+\mathrm{RO}(p<0.001)$ in relation to $\mathrm{HC}$, respectively, as a consequence of these effects. The combination of the protein-FF and protein-RO led to increases in AI of 5.3 and $5.2 \%$, respectively $(p>0.05)$.

Triacylglycerol (TG) plasma concentrations of the animals in groups $\mathrm{HC}+7 \mathrm{~S}$ and $\mathrm{HC}+\mathrm{FF}$ showed significant reductions $(p<0.001)$ of 34.8 and $45.7 \%$, whereas group $\mathrm{HC}+\mathrm{RO}$ had only a slight reduction of $7.6 \%(p>0.05)$, relative to HC. For protein-drug combinations, the $\beta$ conglycinin/fenofibrate group $(\mathrm{HC}+7 \mathrm{~S}+\mathrm{FF})$ did not show

Table 2 Body weight change, food intake, and feeding efficiency ratio (FER) of rats fed HC diets and treated with separate and combined doses of $\beta$-conglycinin, fenofibrate and rosuvastatin

\begin{tabular}{|c|c|c|c|c|c|c|}
\hline & \multicolumn{6}{|c|}{ Dietary groups $^{1}$} \\
\hline & $\mathrm{HC}$ & $\mathrm{HC}+7 \mathrm{~S}$ & $\mathrm{HC}+\mathrm{FF}$ & $\mathrm{HC}+\mathrm{RO}$ & $\mathrm{HC}+7 \mathrm{~S}+\mathrm{FF}$ & $\mathrm{HC}+7 \mathrm{~S}+\mathrm{RO}$ \\
\hline Initial weight (g/rat) & $196.55 \pm 4.63$ & $195.26 \pm 3.64$ & $193.26 \pm 3.64$ & $193.33 \pm 2.27$ & $193.18 \pm 3.62$ & $194.22 \pm 3.14$ \\
\hline Final weight (g/rat) & $295.01 \pm 5.43$ & $300.64 \pm 7.71$ & $281.14 \pm 4.25$ & $306.11 \pm 3.79$ & $306.64 \pm 7.71$ & $284.33 \pm 8.01$ \\
\hline Weight gain (g/rat/day) & $3.51 \pm 0.32$ & $3.76 \pm 0.29$ & $3.14 \pm 0.29$ & $4.02 \pm 0.16$ & $4.05 \pm 0.17$ & $3.22 \pm 0.28$ \\
\hline Food intake (g/rat/day) & $16.74 \pm 0.33$ & $16.25 \pm 0.22$ & $16.25 \pm 0.22$ & $18.20 \pm 0.17^{* *}$ & $15.61 \pm 0.30$ & $17.68 \pm 0.25$ \\
\hline Fecal excretion (g/rat/day) & $3.59 \pm 0.12$ & $2.94 \pm 0.09^{*}$ & $2.94 \pm 0.09^{*}$ & $2.05 \pm 0.12^{* *}$ & $2.83 \pm 0.09^{*}$ & $1.77 \pm 0.13^{* *}$ \\
\hline Feeding efficiency (\%) & $21.01 \pm 1.44$ & $23.05 \pm 1.93$ & $23.21 \pm 1.93$ & $21.35 \pm 0.85$ & $20.90 \pm 1.51$ & $18.25 \pm 1.34$ \\
\hline
\end{tabular}

${ }^{1}$ Values are means \pm SEM for nine rats. ${ }^{*} \mathrm{p}<0.05$ and ${ }^{* *} \mathrm{p}<0.001$ by the Bonferroni t-test for multiple comparisons versus control group (HC). HC $=$ hypercholesterolemic diet; $\mathrm{HC}+7 \mathrm{~S}=\mathrm{HC}$ diet $+\beta$-conglycinin $300 \mathrm{mg} / \mathrm{kg} / \mathrm{day} ; \mathrm{HC}+\mathrm{FF}=\mathrm{HC}$ diet + fenofibrate $30 \mathrm{mg} / \mathrm{kg} / \mathrm{day} ; \mathrm{HC}+\mathrm{RO}=\mathrm{HC}$ diet $+\mathrm{rosuvastatin} 10$ $\mathrm{mg} / \mathrm{Kg} /$ day; $\mathrm{HC}+7 \mathrm{~S}+\mathrm{FF}=\mathrm{HC}$ diet $+\beta$-conglycinin + fenofibrate, 300 and $30 \mathrm{mg} / \mathrm{kg} /$ day respectively, and $\mathrm{HC}+7 \mathrm{~S}+\mathrm{RO}=\mathrm{HC}$ diet $+\beta$-conglycinin + rosuvastatin, 300 and $10 \mathrm{mg} / \mathrm{kg} /$ day respectively. 
Table 3 Tissue weight of rats fed HC diets and treated with doses of $\beta$-conglycinin, fenofibrate, rosuvastatin and mixtures

\begin{tabular}{lcccccc}
\hline & \multicolumn{5}{c}{ Dietary groups $^{\mathbf{1}}$} \\
\cline { 2 - 6 } & HC & HC+7S & HC+FF & HC+RO & HC+7S+FF & HC+7S+RO \\
\hline Liver weight (g/rat) & $13.54 \pm 0.36$ & $13.55 \pm 0.87$ & $21.10 \pm 0.69^{* *}$ & $17.07 \pm 0.92^{*}$ & $19.32 \pm 0.38^{* *}$ & $12.83 \pm 0.51$ \\
Heart (g/rat) & $1.03 \pm 0.04$ & $0.94 \pm 0.03$ & $0.95 \pm 0.03$ & $1.26 \pm 0.05$ & $0.96 \pm 0.02$ & $0.89 \pm 0.05$ \\
Hepatossomatic índex* (HI) & $4.59 \pm 0.14$ & $4.41 \pm 0.20$ & $7.51 \pm 0.27^{* *}$ & $5.56 \pm 0.27^{*}$ & $6.30 \pm 0.12^{* *}$ & $4.63 \pm 0.16$ \\
Heart weight/body weight (g/100 g) & $0.34 \pm 0.01$ & $0.30 \pm 0.02$ & $0.34 \pm 0.01$ & $0.41 \pm 0.02^{*}$ & $0.33 \pm 0.01$ & $0.32 \pm 0.01$ \\
\hline
\end{tabular}

${ }^{1}$ Values are means \pm SEM for nine rats. ${ }^{*} \mathrm{p}<0.05$ and ${ }^{* *} \mathrm{p}<0.001$ by the Bonferroni t-test multiple comparisons versus control group (HC). $\mathrm{HC}=$ hypercholesterolemic diet; $\mathrm{HC}+7 \mathrm{~S}=\mathrm{HC}$ diet $+\beta$-conglycinin $300 \mathrm{mg} / \mathrm{kg} /$ day; $\mathrm{HC}+\mathrm{FF}=\mathrm{HC}$ diet + fenofibrate $30 \mathrm{mg} / \mathrm{kg} / \mathrm{day} ; \mathrm{HC}+\mathrm{RO}=\mathrm{HC}$ diet $+\mathrm{rosuvastatin} 10$ $\mathrm{mg} / \mathrm{kg} /$ day; $\mathrm{HC}+7 \mathrm{~S}+\mathrm{FF}=\mathrm{HC}$ diet $+\beta$-conglycinin + fenofibrate, 300 and $30 \mathrm{mg} / \mathrm{kg} /$ day respectively, and $\mathrm{HC}+7 \mathrm{~S}+\mathrm{RO}=\mathrm{HC}$ diet $+\beta-$ conglycinin + rosuvastatin, 300 and $10 \mathrm{mg} / \mathrm{kg} /$ day respectively. Hepatossomatic índex $(\mathrm{HI})=$ liver weight/body weight $\times 100$.

any change, but the $\beta$-conglycinin/rosuvastatin group $(\mathrm{HC}+7 \mathrm{~S}+\mathrm{RO})$ showed a reduction of $23.9 \%$ in the $\mathrm{TG}$ levels $(p<0.05)$ relative to the respective drug-treated groups ( $\mathrm{HC}+\mathrm{FF}$ and $\mathrm{HC}+\mathrm{RO})$ (Table 4$)$.

\section{Effects on hepatic lipids}

Table 4 shows that groups $\mathrm{HC}+7 \mathrm{~S}$ had reductions of 20.9 and $14.8 \%$ in the liver cholesterol and triacylglycerol concentrations, compared to $\mathrm{HC}$, respectively $(p<0.001)$. Groups $\mathrm{HC}+\mathrm{FF}$ and $\mathrm{HC}+\mathrm{RO}$ had 32.3 and $38.3 \%$ less cholesterol than $\mathrm{HC}$, respectively (Table 4); on the other hand, group $\mathrm{HC}+\mathrm{RO}$ had a $27.3 \%$ reduced liver TG concentration, while $\mathrm{HC}+\mathrm{FF}$ did not show significant alteration in this parameter $(p<0.001)$.

\section{Discussion}

The effects of fibrates and statins as drugs for the treatment of dyslipidemias are well described in the literature and their mechanisms of action practically established $[21,23]$. The action of these compounds is associated with transcriptional control of triglycerides metabolism by the activation of the transcription factor PPAR- $\alpha$ (peroxisome proliferator-activated receptor) and consequent induction of the enzymes of $\beta$-oxidation of fatty acids in mitochondria. Statins inhibit endogenous cholesterol synthesis by inhibition of 3-hydroxy-3-methyl-glutamylCoA reductase, the rate-limiting enzyme in cholesterol synthesis. Depending on which generation of statin is used the various doses lead to reductions of LDL-C (lowdensity lipoprotein cholesterol) in a range between 20 and $60 \%$ [23]. Diet components, such as plant sterols/ stanols, soluble fibers, omega-3-fatty acids, niacin and soybean components; have been combined with a variety of drugs, in experiments in vitro and in vivo, to treat dyslipidemia [18].

In our experiment, the differences in body weight gain between groups were not significant, although the weights of the livers of rats consuming the mixture of drugs and 7S-FF were much higher than those of other groups. The group that received rosuvastatin had a liver weight gain lower than those given fenofibrate. The observed increase in liver weight by administration of fenofibrate is reported in the literature. Yamamoto et al. [22] found such an increase on administering fenofibrate at $0.05 \%$ in diet of rats, while, Mancini et al. [35] observed an increase of $30.2 \%$ in the liver weight of hyperlipidemic rats after daily

Table 4 Effect of diets on plasma lipid profiles and hepatic lipid contents in rats fed hypercholesterolemic diets and treated with doses of $\beta$-conglycinin, fenofibrate, rosuvastatin and mixtures

\begin{tabular}{|c|c|c|c|c|c|c|}
\hline & \multicolumn{6}{|c|}{ Dietary groups } \\
\hline & $\mathrm{HC}$ & $\mathrm{HC}+7 \mathrm{~S}$ & $\mathrm{HC}+\mathrm{FF}$ & $\mathrm{HC}+\mathrm{RO}$ & $\mathrm{HC}+7 \mathrm{~S}+\mathrm{FF}$ & $\mathrm{HC}+7 \mathrm{~S}+\mathrm{RO}$ \\
\hline \multicolumn{7}{|l|}{ Plasma (mmol/L) } \\
\hline Total cholesterol & $3.88 \pm 0.22$ & $2.99 \pm 0.10^{*}$ & $2.49 \pm 0.15^{* *}$ & $3.15 \pm 0.12^{*}$ & $2.33 \pm 0.22^{* *}$ & $4.00 \pm 0.12$ \\
\hline $\mathrm{HDL}-\mathrm{C}$ & $0.45 \pm 0.02$ & $0.70 \pm 0.05^{*}$ & $0.88 \pm 0.13^{*}$ & $0.68 \pm 0.06$ & $0.93 \pm 0.10^{* *}$ & $0.90 \pm 0.15^{*}$ \\
\hline non-HDL-C & $3.43 \pm 0.12$ & $2.29 \pm 0.10^{* *}$ & $1.61 \pm 0.06^{* *}$ & $2.47 \pm 0.14^{* *}$ & $1.39 \pm 0.12^{* *}$ & $2.91 \pm 0.22^{*}$ \\
\hline Triacylglycerides & $0.92 \pm 0.05$ & $0.60 \pm 0.04^{* *}$ & $0.50 \pm 0.02^{* *}$ & $0.85 \pm 0.07$ & $0.49 \pm 0.03^{* *}$ & $0.70 \pm 0.05^{*}$ \\
\hline$A l^{*}$ & $8.09 \pm 0.07$ & $3.52 \pm 0.11^{* *}$ & $1.96 \pm 0.12^{* *}$ & $4.09 \pm 0.35^{* *}$ & $1.53 \pm 0.15^{* *}$ & $3.67 \pm 0.33^{* *}$ \\
\hline \multicolumn{7}{|l|}{ Liver ( $\mu$ mol/g) } \\
\hline Total cholesterol & $58.43 \pm 0.85$ & $46.22 \pm 0.65^{* *}$ & $39.58 \pm 0.85^{* *}$ & $36.04 \pm 2.07^{* *}$ & $37.86 \pm 0.80^{* *}$ & $47.13 \pm 2.12^{* *}$ \\
\hline Triacylglycerides & $56.97 \pm 2.15$ & $48.52 \pm 2.28^{*}$ & $60.06 \pm 1.76$ & $41.42 \pm 2.46^{* *}$ & $47.64 \pm 2.38^{*}$ & $46.05 \pm 2.59^{*}$ \\
\hline
\end{tabular}

${ }^{1}$ Values are means \pm SEM for nine rats. ${ }^{*} \mathrm{p}<0.05$ and ${ }^{* *} \mathrm{p}<0.001$ by the Bonferroni t-test multiple comparisons versus control group (HC). $\mathrm{HC}=$ hypercholesterolemic diet; $\mathrm{HC}+7 \mathrm{~S}=\mathrm{HC}$ diet $+\beta$-conglycinin $300 \mathrm{mg} / \mathrm{kg} /$ day; $\mathrm{HC}+\mathrm{FF}=\mathrm{HC}$ diet + fenofibrate $30 \mathrm{mg} / \mathrm{kg} / \mathrm{day} ; \mathrm{HC}+\mathrm{RO}=\mathrm{HC}$ diet + rosuvastatin 10 $\mathrm{mg} / \mathrm{kg} /$ day; $\mathrm{HC}+7 \mathrm{~S}+\mathrm{FF}=\mathrm{HC}$ diet $+\beta$-conglycinin + fenofibrate, 300 and $30 \mathrm{mg} / \mathrm{kg} /$ day respectively, and $\mathrm{HC}+7 \mathrm{~S}+\mathrm{RO}=\mathrm{HC}$ diet $+\beta$-conglycinin + rosuvastatin, 300 and $10 \mathrm{mg} / \mathrm{kg} /$ day respectively. ${ }^{*} \mathrm{Al}=$ atherogenic index ware calculated as proposed by Liu et al. (2006). 
administration of $320 \mathrm{mg} \cdot \mathrm{kg}^{-1}$ of fenofibrate for 120 days. Ji et al. [36] observed an increase in the liver weight of the animals fed on a hyperlipidemic diet and treated with atorvastatin at a dose of $30 \mathrm{mg} \cdot \mathrm{kg}^{-1}$ day $^{-1}$ for 8 weeks; the authors also showed an increase in the hepatosomatic index of these animals. These results are consistent with published reports of liver hypertrophy after fenofibrate administration, due to proliferation of peroxisomes and mitochondria. In our study, the raised hepatosomatic index of the animals that received fenofibrate thus resulted from the high liver weight and the insignificant body weight gains of the animals (Table 2 and 3 ). The proteindrug combination caused reductions of 16 and $16.7 \%$ in the hepatosomatic indices of the animals that ingested fenofibrate and rosuvastatin, respectively, and in the latter case practically annulled the effect of the drug alone. Therefore, the $\beta$-conglycinin was able to reverse the increase in the liver weight and hepatosomatic index of the animals that ingested rosuvastatin, but not those of the $7 \mathrm{~S}+\mathrm{FF}$ animals.

The protein $\beta$-conglycinin has been studied for its effects on dyslipidemia, both as a single protein added to the diet, and as a daily dose $[7,8,10,12-14,37,38]$, and in both cases distinct effects on lipid metabolism were observed. Studies using animals subjected to a daily dose of $\beta$-conglycinin [13-15], and our study, show that the 7S protein has an effect comparable to that of rosuvastatin, but weaker than fenofibrate, in reducing levels of total cholesterol. Surprisingly, the $\beta$-conglycinin/rosuvastatin combination raised the total cholesterol to a higher level than in any other group, even the hypercholesterolemic group, while the combination with fenofibrate led to lower values of TC than either separately.

The LDL-C/HDL-C ratio is used as risk factor for coronary heart diseases (CHD), on account of the effect of each fraction on the atherosclerotic process [39]. Thus, the atherogenic index (AI) of the hypercholesterolemic diet group (HC), in this experiment, was 8 times higher than that of rats on the casein standard diet [14], as also observed by other authors [10]. All treatments resulted in reductions in $\mathrm{AI}$ of the animals, the combination of $7 \mathrm{~S}$ protein and fenofibrate ( $\mathrm{HC}+7 \mathrm{~S}+\mathrm{FF}$ group) being the most efficient, followed by fenofibrate (HC+FF group), protein $(\mathrm{HC}+7 \mathrm{~S}$ group), protein plus rosuvastatin ( $\mathrm{HC}$ $+7 \mathrm{~S}+\mathrm{RO}$ group) and rosuvastatin ( $\mathrm{HC}+\mathrm{RO}$ group), with falls of $81,76,57,55$ and $50 \%$, relative to $\mathrm{HC}$, respectively (Table 4). These data indicate that the protein-fenofibrate and protein-rosuvastatin combinations resulted in lower cardiovascular risks than did the drugs alone (Table 4). Even though the combination of protein with rosuvastatin rose the level of total cholesterol approximately to that observed in the group $\mathrm{HC}$, the combination reduced the cardiovascular risk by increasing the HDL-C fraction (Table 4).
The mechanisms of action of these drugs are properly established, as mentioned above. However, the mechanisms of action of soybean proteins on lipid metabolism are not yet clear, as various studies point to different actions, such as increasing the amount of LDL-receptors [7,8,40,41], inhibiting HMG-CoA reductase [42], sequestering bile acids [38], activiting $\beta$-oxidation related enzymes $[38,43]$, gene expression $[40,43]$ and others $[11,12,38,41]$. However, a lot of evidence suggests that the effects of soybean proteins could be due to biologically active peptides produced by digestion of the proteins in the gastrointestinal tract, and that these peptides would be the main agents affecting cholesterol and triacylglyceride metabolism, since the protein itself cannot be absorbed intact.

The behaviors of these combinations suggest a possible synergy between the protein and fenofibrate and an antagonistic effect with rosuvastatin, in relation to serum total cholesterol. Although, in the case of rosuvastatin, the increase in the HDL-C fraction to a level above that with the protein or drug alone may be due to a higher rate of cholesterol catabolism, an important function of this fraction is as a carrier of cholesterol to the liver. Fenofibrate has been characterized as a drug that causes an increase in HDL-C levels [44], while the literature indicates only a slight modification of this fraction by the statins, unrelated to dose [20]. These observations were confirmed by our experiment, but $\beta$-conglycinin had a positive effect in combination with rosuvastatin, resulting in a higher increase than with the drug alone. The non-HDL-C levels followed the same trend as total cholesterol. The combinations of protein with the drugs did not affect the TG levels, although the rosuvastatin improved the action of the protein in the combination and reduced the level compared to the drug alone.

The liver cholesterol concentration was reduced by all treatments, relative to $\mathrm{HC}$, the greatest reduction (37\%) being seen in the HC+RO group. Nevertheless, 7S-rosuvastatin combination annulled the effect of the drug, showing the same value as the protein alone and much higher than with the drug alone. The 7S-fenofibrate combination resulted in a fall in concentration of hepatic triacylglycerides, relative to $\mathrm{HC}$ and to the drug alone (which led to a rise in this level), to the same concentration as $\mathrm{HC}$ + FF. However, the fenofibrate, without or with $7 \mathrm{~S}$ protein, maintained the hepatosomatic index above that of the $\mathrm{HC}$ group, due to the appreciable increase in the liver weight of the animals.

The meta-analysis of studies by Anderson et al. [45] demonstrated a $12.5 \%$ reduction in the levels of LDL-C for 1.5 to $2 \mathrm{oz}$ of soy protein daily $(50 \mathrm{~g} / \mathrm{d})$, whereas a recent meta-analysis reported only 4-6\% [46]. More recently, Jenkins et al. [16] discussed the effect of cholesterol reduction by soy proteins in light of a review of 
claims for heart health by the U.S. FDA and a metaanalysis of studies on the action of soy protein; they concluded that soy remains one of the few food components that reduce serum cholesterol when added to the diet. Results in the literature show that soybean protein, when used as the only protein source in the diet affects these serum parameters in various ways, depending on the experimental model, animal, dose and other factors [3]. However, when administered as a daily dose in hypercholesterolemic animals fed a standard casein diet, enriched by cholesterol and cholic acid, it had the effect of reducing TC, LDL-C and TG levels in a dose-dependent manner $[13,14]$. It is important to note that in our study the $\beta$-conglycinin was administered by gavage, alone and/or in combination with the drugs at a concentration equivalent to $2.75-2.90 \%$ of the daily total protein intake, and that the doses were given separately to the animals, with a difference of 6 hours between drug and the protein. The fact that the $\beta$-conglycinin was isolated may be the cause of its higher effect on the cholesterol metabolism relative to the total protein or soybean protein products. We may note that, despite the use of various experimental models with different in vitro and in vivo approaches, the mechanism of action of soy protein on lipid metabolism is still controversial and deserves further study, especially in relation to its interactions with drugs of similar effect. At the moment, studies to reveal the mechanism of action of $\beta$-conglycinin, alone and combined with statins are in progress in our lab.

\section{Conclusion}

The 7S soybean protein-fenofibrate combination was shown to have a positive in reducing the serum total cholesterol levels of hypercholesterolemic animals, as well as raising the levels of HDL-C, and relative to the protein and drug alone. This enhancing effect was reflected in a greater reduction of the cardiovascular risk by up to $81 \%$ relative to $\mathrm{HC}$ animals. This combination also had a positive effect on the levels of hepatic triacylglycerides, with a reduction of $20.6 \%$ relative to the drug alone. The association of protein-rosuvastatin produced an unexpected action on serum total cholesterol, maintaining it at the level shown by the HC group, which was 25 and $21 \%$ higher than those observed with the protein and drug alone. However, it also caused an increase in HDL-C of $23 \%$, compared to protein and drug alone. Surprisingly, it achieved a reduction in the cardiovascular risk of 55\%, relative to group $\mathrm{HC}$.

\section{Acknowledgements and Funding}

This work was supported by FAPESP (Fundação de Amparo à Pesquisa do Estado de São Paulo), (2009/11511-0), FUNDUNESP (00583/07-DFP and 0041/ 10-DFP) and PADC-FCF-UNESP Scientific Program. The authors acknowledge the careful proofreading of the text by Timothy John C. Roberts (MSc).

\section{Authors' contributions}

VAN and ESF designed the research; ESF and MAS conducted the research; ESF, VAN and AD analyzed the data; VAN and ESF wrote the paper; and VAN had primary responsibility for the final content. All authors read and approved the final manuscript.

\section{Competing interests}

The authors declare that they have no competing interests.

Received: 30 November 2011 Accepted: 13 January 2012

Published: 13 January 2012

\section{References}

1. Duranti M: Grain legume proteins and nutraceutical properties. Fitoterapia 2006, 77:67-82.

2. Torres N, Torre-Villalvazo I, Tovar AR: Regulation of lipid metabolism by soy protein and its implication in diseases mediated by lipid disorders. $J$ Nut Biochem 2006, 17:365-373.

3. Sirtori CR, GAlli C, Anderson JW, Arnoldi A: Nutritional and nutraceutical approaches to dyslipidemia and atherosclerosis prevention; Focus on dietary proteins. Atherosclerosis 2009, 203:8-17.

4. Scarafoni A, Magni C, Duranti M: Molecular nutraceutics as a mean to investigate the positive effects of legume seed proteins on human healthy. Trends Food Sci Technol 2007, 18:454-463.

5. Bazzano LA, Thompson AM, Tees MT, Nguyen CH, Winham DM: Non-soy legume consumption lowers cholesterol levels: A meta-analysis of randomized controlled trials. Nutr Metabol Cardiov Dis 2011, 21:94-103.

6. Lovati MR, Manzoni C, Corsini A, Granata A, Fumagalli R, Sirtori CR: Low density lipoprotein receptor activity is modulated by soybean globulins in cell culture. J Nut 1992, 22:1971-1978.

7. Lovati MR, Manzoni C, Corsini A, Granata A, Fumagalli R, Sirtori CR: 7S Globulin from soybean is metabolized in human cell cultures by a specific uptake and degradation system. J Nut 1996, 126:2831-2842.

8. Lovati MR, Manzoni C, Pizzagalli A, Castiglioni S, Duranti M, Magni C: Soy protein peptides regulate cholesterol homeostasis in Hep G2 cells. J Nut 2000, 130:2543-2549.

9. Rho SJ, Park SP, Ahn CW, Shin JK, Lee HG: Dietetic and hypocholesterolaemic action of black soy peptide in dietary obese rats. J Sci Food Agric 2007, 87:908-913.

10. Aoyama T, Kohno M, Saito T, Fukui K, Takamatsu K, Yamamoto T: Reduction by phytate-reduced soybean conglycinin of plasma triglyceride level of young and adult rats. Biosc Biotech Biochem 2001, 65:1071-1075.

11. Fukui K, Tachibana N, Wanezaki S, Tsuzaki S, Takamatsu K, Yamamoto T, Hashimoto $Y$, Shimoda T: Isoflavone-free soy protein prepared by column chromatography reduces plasma cholesterol in rats. J Agric Food Chem 2002, 50:5717-5721.

12. Fukui K, Kojima M, Tachibana N, Kohno M, Takamatsu K, Hirotsuka M, Kito M: Effects of soybean conglycinin on hepatic lipid metabolism and fecal lipid excretion in normal adult rats. Biosc Biotech Biochem 2004 68:1153-1155.

13. Duranti M, Lovati MR, Dani V, Barbiroli A, Scarafoni A, Castiglioni S, Ponzone C, Morazzoni P: The subunit from soybean 75 globulin lowers plasma lipids and upregulates liver VLDL receptors in rats fed a hypercholesterolemic diet. J Nut 2004, 134:1334-1339.

14. Ferreira ES, Silva MA, Demonte A, Neves VA: $\beta$-conglycinin (7S) and glycinin (11S) exert a hypocholesterolemic effect comparable to that of fenofibrate in rats fed high-cholesterol diet. J Func Foods 2010, 2:275-283.

15. Ferreira ES, Silva MA, Demonte A, Neves VA: Soy $\beta$-conglycinin (7S globulin) reduces plasma and liver cholesterol in rats fed hypercholesterolemic diet. J Med Food 2011, 14:94-100.

16. Jenkins DJA, Mirrahimi A, Srichaicul K, Berryman CE, Wang L, Carleton A, Abdulnour S, Sievenpiper II, Kendall CWC, Kris-Etherton PM: Soy protein reduces serum cholesterol by both intrinsic and food displacement mechanism. J Nut 2010, 140:23025-2311S.

17. Food and Drug Administration (FDA) Food labeling: health claims; soybean protein and coronary heart disease. Federal register, rules and regulations 1999, 64:57700-57733.

18. Redeout TC, Hrading ST, Marinangeli CPF, Jones PJH: Combination drugdiet therapies for dyslipidemia. Trans/ Res 2010, 155:220-227.

19. Poli A, Marangoni F, Paoletti R, Mannarino E, Lupattelli G, Notarbartolo A, Aureli P, Bernini F, Cicero A, Gaddi A, Catapano A, Cricelli C, Gattone M, 
Marroco W, Porrini M, Stella R, Vanotti A, Volpe M, Volpe R, Cannella C, Pinto A, Del Toma E, La Vecchia C, Tavani A, Manzato E, Ricardi G, Sirtori C, Zambon A: Non-pharmacological control of plasma cholesterol levels. Nut Metabol Cardiov Dis 2008, 18:S1-S16.

20. Xydakis AM, Ballantyne CM: Combination therapy for combined dyslipidemia. Am J Cardiol 2002, 90:21K-29K.

21. Ferreira AVM, Parreira GG, Green A, Botion LM: Effects of fenofibrate on lipid metabolism in adipose tissue of rats. Metabol Clin Experimtl 2006, 55:731-735.

22. Yamamoto K, Fukuda N, Zhang L, Sakai T: Altered hepatic metabolism of fatty acids in rats fed hypolipidaemic drug, fenofibrate. Pharmacol Res 1996, 33:337-342.

23. Kobayashi M, Chisaki I, Narumi K, Hidaka K, Kagawa T, Itagaki S, Hirano T, Iseki K: Association between risk of myopathy and cholesterol-lowering effect: A comparison of all statins. Life Sci 2008, 82:969-975.

24. Nagano T, Hirotsuka M, Mori H, Kohyama K, Nishinari K: Dynamic viscoelastic study on the gelation of $7 \mathrm{~S}$ globulin from soybeans. J Agric Food Chem 1992, 40:941-944.

25. Lowry OH, Rosebrough NJ, Farr AL, Randall RJ: Protein measurement with the folin-phenol reagent. J Biol Chem 1951, 193:265-275.

26. Laemmli UK: Cleavage of structural proteins during the assembly of the head of bacteriophage T4. Nature 1970, 227:680-684.

27. Reeves PG, Nielsen FH, Fahey GC: AIN-93 purified diets for laboratory rodents: final report of the American Institute of Nutrition ad hoc writing committee on the reformulation of the AIN-76A rodent diet. $J$ Nut 1993, 123:1939-1951.

28. Nath N, Wiener R, Harper AE, Elvehjem CA: Diet and cholesterolemia. I. Development of a diet for the study of nutritional factors affecting cholesterolemia in the rat. J Nut 1959, 67:289-307.

29. Stockbridge H, Hardy Rl, Glueck CJ: Photometric determination of cholesterol (CHOD-PAP method). J Labor Clin Med 1989, 114:142-151.

30. Assmann G: HDL-cholesterol precipitant. Randox Labs. Ltd. Crumlin Co. Antrim Northern Ireland Internist; 1979:20:559.

31. Annoni G, Botasso BM, Ciaci D, Donato MF, Tripodi A: Liquid triglycerides (GPO-PAP). Medi Diagnostic Italy. J Labor Clin Med 1982, 9:115.

32. Liu JR, Wang SY, Chen MJ, Chen HL, Yuerh PY, Lin CW: Hypocholesterolaemic effects of milk-kefir and soyamilk-kefir in cholesterol-fed hamsters. British J Nut 2006, 95:939-946.

33. Haug A, Hostmark AT: Lipoprotein lipases, ljpoproteins and tissue lipids in rats fed fish oil or coconut oil. J Nut 1987, 117:1011-1017.

34. Wang YM, Zhang B, Xue Y, Li ZJ, Wang JF, Yanagita T: The mechanism of dietary cholesterol effects on lipid metabolism in rats. Nut Met Card Res 2010, 9:4.

35. Mancini FP, Lanni A, Sabatino L, Moreno M, Giannino A, Contaldo F, Colantuoni V, Goglia F: Fenofibrate prevents and reduces body weight gain and adiposity in diet-induced obese rats. FEBS Letter 2001, 491:154-158

36. Ji G, Shao X, Leng L, Liu P, Jiang Z: Comparison of dietary control and atorvastatin on high fat diet induced hepatic steatosis and hyperlipidemia in rats. Lip Health Dis 2011, 10:23-32.

37. Kohono M, Hirotsuka M, Kito M, Matsuzawa Y: Decreases in serum triacylglycerol and visceral fat mediated by dietary soybean $\beta$ conglycinin. J Atherosd Thromb 2006, 13:247-255.

38. Moriyama T, Kishimoto K, Nagai K, Urade R, Ogawa T, Utsumi $\mathrm{S}$, Maruyama N, Maebuchi M: Soybean $\beta$-conglycinin diet suppresses serum triglyceride level in normal and genetically obese mice by induction of beta-oxidation, down regulation of fatty acid synthase, and inhibition of triglyceride absorption. Biosc Biotech Biochem 2004, 68:352-359.

39. Castelli WP, Garrison RJ, Wilson PWF, Abbott RD, Kalousdian S, Kannel WB Incidence of coronary heart disease and lipoprotein cholesterol levels: the Framingham Study. J Amer Med Assoc 1986, 256:2835-2838.

40. Mochizuki Y, Maebuchi M, Kohno M, Hirotsuka M, Wadahama H, Moryiama T, Kawada T, Urade R: Changes in lipid metabolism by soy $\beta$ conglycinin-derived peptides in HepG2 cells. J Agric Food Chem 2009, 57:1473-1480.

41. Adams MR, Golden DL, Franke AA, Potter SM, Smith HS, Anthony MS: Dietary Soy B-Conglycinin (7S Globulin) Inhibits Atherosclerosis in Mice. J Nut 2004, 134:511-516.

42. Pak W, Koo M, Kasimova TD, Kwon DY: Isolation and identification of peptides from soy 11S-globulin with hypocholesterolemic activity. Chem Nat Comp 2005, 41:710-714.
43. Ascencio C, Torres N, Isoard-Acosta F, Gómez-Pérez F J, Hernández-Pando R, Tovar AR: Soy Protein Affects Serum Insulin and Hepatic SREBP-1 mRNA and Reduces Fatty Liver in Rats. J Nut 2004, 134:522-529.

44. Depres JP: Increasing high-density lipoproteins cholesterol: an update on fenofibrate. Am J Cardiol 2001, 88:30N-6N.

45. Anderson JW, Johnstone BM, Cook-Newel ME: Meta-analysis of the effects of soy protein intake on serum lipids. N Engl J Med 1995, 333:276-282

46. Harland Jl, Haffner TA: Systematic review, meta-analysis and regression randomized controlled trials reporting an association between an intake of circa $25 \mathrm{~g}$ soya protein per day and blood cholesterol. Atherosclerosis 2008, 200:13-27.

doi:10.1186/1476-511X-11-11

Cite this article as: Ferreira et al:: $\beta$-conglycinin combined with fenofibrate or rosuvastatin have exerted distinct hypocholesterolemic effects in rats. Lipids in Health and Disease 2012 11:11.

\section{Submit your next manuscript to BioMed Central and take full advantage of:}

- Convenient online submission

- Thorough peer review

- No space constraints or color figure charges

- Immediate publication on acceptance

- Inclusion in PubMed, CAS, Scopus and Google Scholar

- Research which is freely available for redistribution

Submit your manuscript at www.biomedcentral.com/submit
C Biomed Central 